\title{
COURSEWARE EVALUATION BY TEACHERS: AN IMPLEMENTATION PERSPECTIVE
}

\author{
JOKE VOOGT \\ Department of Education, University of Twente, P.O. Box 217, 7500 AE Enschede. The Netherlands
}

(Received 6 July 1989; amended 7 December 1989)

\begin{abstract}
This study has investigated teachers' criteria for the use of courseware packages in the classroom. The starting point of the study was the assumption that it is the teacher who decides whether or not courseware will be used in the classroom. The integration of courseware into the curriculum is conceived as a complex innovation. The study is oriented towards the process of decision making by teachers. A positive decision to actual use of courseware is one of the first steps towards integration of courseware into the curriculum. Three determinants of quality and practicality of an innovation, viz. instrumentality, congruence and cost, formed the theoretical framework of the study. From the study it can be concluded that at the very first stage of the process leading to the integration of courseware into the curriculum, courseware should motivate students, realize educational objectives better than traditional methods and its content should be an operationalization of teacher's ideas and beliefs.
\end{abstract}

\section{INTRODUCTION}

At the subject level teachers play a central role in the integration of courseware* into the curriculum. In the end it is the teacher who usually decides about the use of courseware in his (her) lessons. The integration of courseware into the curriculum can be conceived as a major innovation for most teachers[2].

In this study existing courseware has been evaluated by teachers. The objective of the study was to find courseware characteristics which were of decisive importance to teachers in relation to classroom use of courseware. The study had an exploratory character and was part of a larger project concerning the design of courseware for the teaching of science process skills in the junior high school physics curriculum. From the present study design specifications for courseware will be generated.

The process of educational change has three stages, viz. adoption, implementation and incorporation [3]. Adoption leads to the decision to use an innovation. Implementation is the process of putting a change into practice[3]. Implementation in itself can lead to the incorporation of the innovation in its environment. Although the three stages can be distinguished in the process of educational change, they are partly overlapping. This study focuses on the initial use of courseware in the curriculum. The theoretical framework of this study is, therefore, based on literature about the transition domain between adoption and implementation.

Fullan [3] states that the quality and practicality of the materials which are part of the innovation influence the implementation of an innovation. To promote the implementation of the integration of courseware in the curriculum, knowledge about determinants of quality and practicality of courseware as perceived by teachers are of vital importance.

Doyle and Ponder [4] introduced the term "practicality ethic" for the way practising teachers react to innovations. They pointed out three general dimensions-instrumentality, congruence and cost - of a change proposal, which determine whether an innovation is being perceived as practical by teachers. Instrumentality refers to how clearly and specifically the innovation is presented. Congruence describes how well the innovation is aligned with the teacher's present teaching philosophy and practices. Cost is the teacher's estimate of the extra time and effort the innovation requires compared with the benefits the innovation is likely to yield.

D'Arcy and Gardner [5] have investigated teachers' perception of good courseware. Their study showed that good courseware must be flexible, alterable, relevant, valid (correct educational

*According to Bunderson[1] courseware refers to computer programs and all other accompanying materials. 
content and justifiable computer use), motivating, portable and friendly. They suggest that the views of teachers provide the most appropriate guidelines for courseware development.

The courseware characteristics found by D'Arcy and Gardner[5] can partly be considered as a further specification of the dimensions instrumentality, congruence and cost. Relevance (courseware must have curricular relevance) refers to congruence. The demand that courseware must be flexible (useful for a range of ages and abilities), justifiable and motivating students refers to a weighing of benefits and effort.

D'Arcy and Gardner's claims of valid (correct educational content) and user friendly courseware can be conceived as a necessary condition for classroom use of courseware. Portability, which refers to the possibility of using courseware on many different types of hardware, is an important technical condition but not a substantial claim. According to the findings of D'Arcy and Gardner courseware should be alterable. However, investigations $[2,6]$ about the use of curriculum materials show that initial use - as is the case in this study - is promoted through a detailed design. Also for the use of so called 'open-ended' courseware it seems important that some worked out examples are part of the courseware.

Because the study focuses on initial computer use portability and alterability are not further considered in this study.

In the study teachers review existing courseware on its practicality for classroom use. The three dimensions of the practicality ethic (Doyle and Ponder) and D'Arcy and Gardner's claims of valid and user friendly courseware serve as working hypotheses for the construction of instruments in the study.

\section{METHOD}

\section{Instruments}

Based on an existing Dutch instrument [7] for courseware evaluation, a courseware evaluation instrument was developed in which the dimensions instrumentality, congruence and cost and the necessary conditions for good courseware (validity and friendliness) have been operationalized as follows:

(1) Characteristics which are important for teacher decision making: Instrumentality: are specific and clear teacher instructions for classroom use part of the courseware package?

Congruence: does the courseware package fit into classroom practice and into the curriculum?

Cost: are efforts to use the courseware package compensated by expected benefits: is the courseware package motivating for students, justifiable and flexible?

(2) Necessary conditions for the use of courseware:

Validity: is the educational content correct?

Friendliness: is the courseware simple and consistent in its operation?

A questionnaire has been developed to gather background information about actual classroom practice and computer experience of the teachers. In a pilot study two teachers tested the instruments.

\section{Selection of courseware}

Three courseware packages have been selected. The subject matter of all three packages fits into the junior high school physics curriculum. A working session with each package is possible within a class period $(45-50 \mathrm{~min})$ and at least one science process skill is being taught by a package. It was not possible to find three courseware packages in Dutch which satisfy these demands, so one package is in English. This choice can be justified, because the study has an exploratory character and because the courseware is not used with students. In the pilot study the courseware has been checked on these demands.

The three packages can be characterized as follows:

Package $A$ is a drill and practice program. Aimed objective (not explicitly stated): students are able to read scales of (seven) measuring-instruments fast and precisely. Description of the program: 
After an instrument is chosen (menu), the computer generates random measuring points on (if possible) different scales. With the chosen instrument students can practice as long as they want. For every reading only one answer can be given. A wrong answer is accompanied by feedback. The computer gives two types of feedback: an indication about the way the right answer is acquired or information about the accuracy of the answer. Students can-at every moment-ask for the number of right and wrong answers. Teacher instructions in the form of accompanying written material are part of the program. This material consists of a description of the program, information about advance knowledge of students, some suggestions for use in the classrooms and a user manual.

Package $B$ is a simulation. Aimed objective (not explicitly stated): students are able to investigate and build an electric circuit. Description of the program: on the screen students see 3 or 4 bulbs and a battery. With a mouse one can either connect or disconnect each bulb and see whether the other bulbs will burn or not. In this way students enquire about the underlying electric circuit. If one has an idea about the electric circuit a scheme of the circuit can be built on the screen with the mouse and a number of icons. Students can test the scheme and see if scheme and circuit tally. Students can go on with investigating, building and testing a certain circuit as long as they want, but can investigate a new circuit at any moment as well. The students use their own problem-solving strategy. Students choose between simple, normal and difficult circuits. Teacher instructions in the form of accompanying written material are not part of the program. However, there is a help-program with a user manual and a description of the assignment for the students.

Package $C$ is a tutorial. Aimed objective (explicitly stated): "Reflections is to teach the process of theory construction", more specific (explicitly stated): "-determine how a light beam leaves a flat mirror; - state which factors are important and which are not; - test a tentative law or hypothesis concerning the reflection of light; - determine if two angles are approximately equal by inspection". Description of the program: students choose a module (menu). When you start the program for the first time you are expected to choose the first module. Students take the modules successively: (1) hitting the target: the concept of reflection is introduced through an (simulated) experiment; (2) moving the target; (3) the first rules for aiming: tentative theories are given, students explore whether there is something wrong with these theories; (4) factors that affect aiming: students use the computer to perform (simulated) experiments considering the factors that might influence aiming; (5) a better rule for aiming: through observation the law of reflection is developed and verified by students with further evidence. Dependent on the answers of the students the program reacts differently. However, after giving a wrong answer several times the right answer is given by the program. At any moment students can quit the program. The speed of presentation can be adapted. Teacher instructions in the form of accompanying written material are part of the program. This material consists of a general program description, educational objectives of the program, activities (a short description of each module), curriculum integration suggestions and a user manual.

\section{Subjects}

Twenty-eight physics teachers from fourteen schools evaluated courseware packages on their practicality for classroom use. All teachers had practical teaching experience in junior high school. Average teaching experience was more than 14 years $(X=14.4, S D=7.0)$. All teachers were male.

Computer experience was not important at the recruitment of the teachers. Table 1 shows the number of teachers that knew and/or used computer applications in their physics class. Table 2 shows how many teachers knew used how many different types of applications.

\section{Procedure}

The teachers came to the University for the evaluation of two (of the three) courseware packages. They started with the questionnaire on background information. The assignment of the packages was at random. Courseware package $\mathrm{A}$ has been evaluated by 18 teachers, the packages $\mathrm{B}$ and $\mathrm{C}$ by 19 teachers.

The data have been analyzed for each package. Teachers have been classified as teachers with no (does not know any application, Table 2), some (knows 1 or 2 applications) or much (knows 4 or 5 applications) knowledge of computer applications. The data have also been analysed according to this classification for the combined packages. 
Table I. Number of teachers knowing and using computer applications in physics $(N=28)$

\begin{tabular}{lcc}
\hline & $\begin{array}{c}\text { Knew } \\
\text { application }\end{array}$ & $\begin{array}{c}\text { Used } \\
\text { application in } \\
\text { physics class }\end{array}$ \\
\hline Database & 12 & 0 \\
Simulations & 17 & 5 \\
Drill and practice & 11 & 5 \\
Tutorials & 9 & 3 \\
Microcomputer based laboratory & 13 & 4 \\
\hline
\end{tabular}

Table 2. Number of teachers in relation to number of different types of applications $(N=28)$

\begin{tabular}{lc}
\hline No. of applications & Vo. of teachers \\
\hline Did not know any application & 10 \\
Knew I or 2 applications & 6 \\
Knew 3 applications & 0 \\
Knew 4 or 5 applications & 12 \\
Did not use any application & 22 \\
Used 1 application & 0 \\
Used 2 applications & 3 \\
Used 3 or 4 applications & 3 \\
\hline
\end{tabular}

\section{RESULTS}

\section{Teachers' evaluations of the packages}

First it has been verified if the evaluated packages satisfy the necessary conditions for the use of courseware: validity and friendliness. Validity refers to a correct educational content. Friendliness points to the extent courseware is simple and consistent in its operation. Table 3 presents an evaluation of the validity and friendliness of the packages indicating the frequency with which validity and friendliness have been reported as "weak" and (in italics) the frequency with which this was considered to be of decisive importance when assessing the suitability of the packages for classroom use.

Table 3 shows that in only a few teachers' evaluations validity and friendliness are mentioned as weak points. For actual use of a package weak points in validity and friendliness are not considered of decisive importance. So it can be said that all three packages satisfy the necessary conditions for the use of courseware.

The proportion of teachers actually willing to use the evaluated package (provided that the condition of the availability of sufficient and compatible hardware is realized) is $64.7 \%$ for package A $(N=17$, total number of evaluations), $58.8 \%$ for package B $(N=17$, total number of evaluations) and $70.6 \%$ for package $\mathrm{C}(N=17$, total number of evaluations). So an average of $64.7 \%$ of the final evaluations were positive. In five cases a final evaluation could not be interpreted or has not been made. Table 4 presents the final evaluation results of teachers with no, some or much knowledge about computer applications for physics education.

Table 4 shows that the more knowledge teachers have about computer applications the less positive they judge the usefulness of the packages in the classroom. This is the case for all the packages. The number of evaluations per package is small however, so these results must be taken with caution.

\section{Instrumentality}

Instrumentality points to concrete and specific teacher instructions for use of the courseware in the classroom. Table 5 presents an evaluation of the instrumentality of the packages indicating the frequency with which instrumentality has been reported either as "strong" or as "weak" and (in italics) the frequency with which this characteristic was considered to be of decisive importance when

Table 3. Evaluation of weak points in validity and friendliness. Per package, for all packages and in relation to knowledge of computer applications (values in \%)

\begin{tabular}{|c|c|c|c|c|c|c|c|}
\hline & \multicolumn{3}{|c|}{ Package } & \multirow[b]{2}{*}{ Total } & \multicolumn{3}{|c|}{ Knowledge } \\
\hline & A & $\mathbf{B}$ & C & & None & Some & Much \\
\hline $\begin{array}{l}N \text { (No. of evaluations) } \\
\text { Validity }\end{array}$ & 18 & 19 & 19 & 56 & 20 & 12 & 24 \\
\hline Incorrect educational content & $\begin{array}{r}11.1 \\
0.0\end{array}$ & $\begin{array}{l}0.0 \\
0.0\end{array}$ & $\begin{array}{r}15.8 \\
5.3\end{array}$ & $\begin{array}{l}8.9 \\
1.8\end{array}$ & $\begin{array}{l}5.0 \\
0.0\end{array}$ & $\begin{array}{r}16.7 \\
0.0\end{array}$ & $\begin{array}{l}8.3 \\
4.2\end{array}$ \\
\hline $\begin{array}{l}\text { Friendliness } \\
\text { Not enough user friendly }\end{array}$ & $\begin{array}{l}0.0 \\
0.0\end{array}$ & $\begin{array}{r}21.1 \\
5.3\end{array}$ & $\begin{array}{r}21.1 \\
5.3\end{array}$ & $\begin{array}{r}14.3 \\
3.6\end{array}$ & $\begin{array}{r}10.0 \\
5.0\end{array}$ & $\begin{array}{l}8.3 \\
8.3\end{array}$ & $\begin{array}{r}20.8 \\
0.0\end{array}$ \\
\hline
\end{tabular}

Table 4. Proportion of positive evaluations in relation to knowledge of applications

\begin{tabular}{lll}
\hline No knowledge & 76.5 & $N=17$, total number of evaluations \\
Some knowledge & 66.7 & $N=12$, total number of evaluations \\
Much knowledge & 54.5 & $N=22$, total number of evaluations \\
\hline
\end{tabular}


Table 5. Evaluation of strong and weak points in instrumentality. Per package, for all packages and in relation to knowledge of computer applications (values in \%)

\begin{tabular}{|c|c|c|c|c|c|c|c|}
\hline & \multicolumn{3}{|c|}{ Package } & \multirow[b]{2}{*}{ Total } & \multicolumn{3}{|c|}{ Knowledge } \\
\hline & A & B & C & & None & Some & Much \\
\hline$N$ (No. of evaluations) & 18 & 19 & 19 & 56 & 20 & 12 & 24 \\
\hline Strong points & & & & & & & \\
\hline Concrete tedcher instructions & $\begin{array}{l}5.6 \\
0.0\end{array}$ & $\begin{array}{l}0.0 \\
5.3\end{array}$ & $\begin{array}{l}10.5 \\
10.5\end{array}$ & $\begin{array}{l}5.4 \\
5.4\end{array}$ & $\begin{array}{l}10.0 \\
10.0\end{array}$ & $\begin{array}{l}8.3 \\
8.3\end{array}$ & $\begin{array}{l}0.0 \\
0.0\end{array}$ \\
\hline Weak points & & & & & & & \\
\hline Concrete teacher instructions are missing & $\begin{array}{r}16.7 \\
5.3\end{array}$ & $\begin{array}{l}47.4 \\
10.5\end{array}$ & $\begin{array}{r}31.6 \\
5.3\end{array}$ & $\begin{array}{r}32.1 \\
7.1\end{array}$ & $\begin{array}{l}30.0 \\
15.0\end{array}$ & $\begin{array}{r}25.0 \\
0.0\end{array}$ & $\begin{array}{r}37.5 \\
4.2\end{array}$ \\
\hline
\end{tabular}

assessing the suitability of the packages for classroom use. As Table 5 shows, in quite a number of evaluations lack of concrete teacher instructions is marked as a weak point of the packages. In most evaluations, however, lack of teacher instructions is not judged to be of decisive importance for actual classroom use. Nevertheless, there is a difference between the evaluations of teachers without (none) and with (some or much) knowledge of computer applications of the importance attached to teacher instructions.

\section{Congruence}

Congruence refers to the extent to which a package-according to teachers' perceptions-fits into classroom practice and into the curriculum. Table 6 presents an evaluation of the congruence of the packages indicating the frequency with characteristics of congruence have been reported either as "strong" or as "weak" and (in italics) the frequency with which these characteristics were considered to be of decisive importance when assessing the suitability of the packages for classroom use.

Table 6 shows that fitting the packages into classroom practice is neither a very strong nor a very weak point. For only a very few evaluations it is, with a view to actual classroom use, of decisive importance.

Further results of the study show that in about half $(51.8 \%)$ of the evaluations a change in the teacher's task is expected. These changes particularly concern the guidance of small group work $(37.5 \%)$ and classroom organization $(21.4 \%)$. Quite a number of teachers $(57.1 \%)$ say they often work in small groups. So a task change concerning guidance of small groups is probably a relatively small change for physics teachers.

Fitting the content of a package into current physics education seems for teachers to be of more importance. It is a rather strong point for the three packages (Table 6 ) and in $25 \%$ of the evaluations of decisive importance. Its antipole "content does not fit into current education" is not important at all. Particularly in nearly half of the evaluations of teachers with some knowledge of computer applications, fitting of the content is of decisive importance. The subject matter of all three packages fits into the junior high school physics curriculum. Content, therefore, probably refers to ideas and beliefs teachers have about physics education for junior high school. Different scores for the packages on this issue reflect these ideas and beliefs. So, it can be said that package C, where students discover a theory about reflection, reflects ideas and beliefs of quite a lot of teachers in the study.

Table 6. Evaluation of strong and weak points in congruence. Per package, for all packages and in relation 10 knowledge of computer applications (values in \%)

\begin{tabular}{|c|c|c|c|c|c|c|c|}
\hline & \multicolumn{3}{|c|}{ Package } & \multirow[b]{2}{*}{ Total } & \multicolumn{3}{|c|}{ Knowledge } \\
\hline & A & B & $\mathrm{C}$ & & None & Some & Much \\
\hline No. of evaluations & 18 & 19 & 19 & 56 & 20 & 12 & 24 \\
\hline \multicolumn{8}{|l|}{ Strong points } \\
\hline Content fits well & 44.8 & 31.6 & 63.2 & 46.4 & 45.0 & 50.0 & 45.8 \\
\hline into current education & 16.7 & 21.1 & 36.8 & 25.0 & 20.0 & 41.6 & 20.8 \\
\hline Package fits well in & 11.1 & 15.8 & 36.1 & 21.4 & 25.0 & 8.3 & 25.0 \\
\hline classroom practice & 5.6 & 0.0 & 10.2 & 5.4 & 10.0 & 8.3 & 0.0 \\
\hline \multicolumn{8}{|l|}{ Weak points } \\
\hline Content does not fit & 0.0 & 10.5 & 10.5 & 7.1 & 0.0 & 8.3 & 12.5 \\
\hline into current education & 0.0 & 10.5 & 5.3 & 5.4 & 0.0 & 8.3 & 8.3 \\
\hline Package does not fit & 5.6 & 31.6 & 5.3 & 14.3 & 15.0 & 25.0 & 8.3 \\
\hline in classroom practice & 0.0 & 15.8 & 5.3 & 7.1 & 5.0 & 16.7 & 4.2 \\
\hline
\end{tabular}


Table 7. Instructional approach of a package (values in \%)

\begin{tabular}{|c|c|c|c|}
\hline \multirow[b]{2}{*}{ Instructional approach } & \multicolumn{3}{|c|}{ Package } \\
\hline & $A$ & B & c \\
\hline No. of evaluations & 14 & 14 & 18 \\
\hline $\begin{array}{l}\text { Explanation of concepts, rules and } \\
\text { theories followed by exercises }\end{array}$ & 0.0 & 7.1 & 0.0 \\
\hline $\begin{array}{l}\text { Guided discovery of concepts. rules } \\
\text { and theories by students }\end{array}$ & 0.0 & 7.1 & 83.3 \\
\hline $\begin{array}{l}\text { Free discovery of concepts, rules } \\
\text { and theories by students }\end{array}$ & 7.1 & 28.6 & 16.7 \\
\hline Only exercises & 85.7 & 50.0 & 0.0 \\
\hline Else & 7.1 & 7.1 & 0.0 \\
\hline
\end{tabular}

The evaluation of the instructional approach of the packages partly reflects teachers' ideas and beliefs about physics education as well. In Table 7 the instructional approach of each package as perceived by teachers is presented. As Table 7 shows package $C$ has-according to teachers-a guided discovery approach. With caution it can be said that it is the approach of guided discovery in package $\mathrm{C}$ which fits most in the ideas and beliefs teachers have about physics education in junior high school.

In addition Table 7 shows that the instructional approach of package B, where students investigate and build electric circuits, is very unclear for teachers.

\section{Cost}

Cost refers to teachers' estimation of benefits as compared to time and effort the use of courseware requires. Table 8 presents an evaluation of the cost of the packages indicating the frequency with which characteristics of cost has been reported either as "strong" or as "weak" and (in italics) the frequency" with which these characteristics were considered to be of decisive importance when assessing the suitability of the packages for classroom use.

As Table 8 shows both strong and weak points concerning cost score rather high. "Time saving", either as a strong or a weak point, is only of decisive importance in a few evaluations. At this early point in the implementation process teachers seem not very much concerned with the time the use of courseware costs. "Better realization of educational objectives" and "motivating for students" seem to be strong points of decisive importance in quite a number of evaluations. However, they have their antipole. Both points will be analysed in more detail.

On the one hand "better realization of educational objectives" is a strong point in about $44 \%$ of the evaluations, and in about $30 \%$ it is of decisive importance. On the other hand in quite a number of evaluations (about 30\%) "objectives are realized more efficiently in another way" is considered as a weak point. In about $16 \%$ this weak point is of decisive importance in relation to the use of a package in the classroom. "Better realization of educational objectives' scores particularly high in evaluations from teachers with no knowledge of computer applications, while teachers with much knowledge of applications doubt the impact of the packages at this point. Their

Table 8. Evaluation of strong and weak points in cost. Per package. for all packages and in relation to knowledge of computer applications (values in \%)

\begin{tabular}{|c|c|c|c|c|c|c|c|}
\hline & \multicolumn{3}{|c|}{ Package } & \multirow[b]{2}{*}{ Total } & \multicolumn{3}{|c|}{ Knowledge } \\
\hline & A & B & $\mathrm{C}$ & & None & Some & Much \\
\hline No. of evaluations & 18 & 19 & 19 & 56 & 20 & 12 & 24 \\
\hline $\begin{array}{l}\text { Strong points (benefits) } \\
\text { A part of mv educational object }\end{array}$ & & & & & & & \\
\hline can be better realized & $\begin{array}{l}72.2 \\
50.0\end{array}$ & $\begin{array}{l}21.1 \\
10.5\end{array}$ & $\begin{array}{l}42.1 \\
31.6\end{array}$ & $\begin{array}{l}44.6 \\
30.4\end{array}$ & $\begin{array}{l}70.0 \\
50.0\end{array}$ & $\begin{array}{l}33.3 \\
33.3\end{array}$ & $\begin{array}{l}29.1 \\
12.5\end{array}$ \\
\hline Motivating for students & $\begin{array}{l}50.0 \\
27.8\end{array}$ & $\begin{array}{l}52.6 \\
36.8\end{array}$ & $\begin{array}{l}58.4 \\
47.4\end{array}$ & $\begin{array}{l}57.1 \\
37.5\end{array}$ & $\begin{array}{l}70.0 \\
25.0\end{array}$ & $\begin{array}{l}50.0 \\
50.0\end{array}$ & $\begin{array}{l}50.0 \\
41.6\end{array}$ \\
\hline In the long run time saving & $\begin{array}{r}27.8 \\
5.6\end{array}$ & $\begin{array}{l}31.6 \\
15.8\end{array}$ & $\begin{array}{l}36.8 \\
21.1\end{array}$ & $\begin{array}{l}32.1 \\
14.3\end{array}$ & $\begin{array}{l}35.0 \\
10.0\end{array}$ & $\begin{array}{l}25.0 \\
25.0\end{array}$ & $\begin{array}{l}33.3 \\
12.5\end{array}$ \\
\hline $\begin{array}{l}\text { Weak points (efforts) } \\
\text { Objectives can be realized more }\end{array}$ & & & & & & & \\
\hline in another way & $\begin{array}{l}11.1 \\
11.1\end{array}$ & $\begin{array}{l}36.8 \\
21.1\end{array}$ & $\begin{array}{l}42.1 \\
15.8\end{array}$ & $\begin{array}{l}30.4 \\
16.1\end{array}$ & $\begin{array}{r}15.0 \\
5.0\end{array}$ & $\begin{array}{r}33.3 \\
8.3\end{array}$ & $\begin{array}{l}41.6 \\
29.2\end{array}$ \\
\hline Not motivating for students & $\begin{array}{r}11.1 \\
5.6\end{array}$ & $\begin{array}{l}36.8 \\
26.3\end{array}$ & $\begin{array}{l}10.5 \\
10.5\end{array}$ & $\begin{array}{l}19.6 \\
14.3\end{array}$ & $\begin{array}{l}15.0 \\
10.0\end{array}$ & $\begin{array}{r}25.0 \\
8.3\end{array}$ & $\begin{array}{l}50.0 \\
20.8\end{array}$ \\
\hline In the long run not time saving & $\begin{array}{r}27.8 \\
0.0\end{array}$ & $\begin{array}{l}42.1 \\
15.8\end{array}$ & $\begin{array}{r}47.5 \\
0.0\end{array}$ & $\begin{array}{r}39.3 \\
5.4\end{array}$ & $\begin{array}{r}40.0 \\
5.0\end{array}$ & $\begin{array}{r}16.7 \\
0.0\end{array}$ & $\begin{array}{r}50.0 \\
8.3\end{array}$ \\
\hline
\end{tabular}




$\begin{aligned} & \text { Table 9. Motivating and not motivating elements for students according to } \\
& \text { (eachers evaluations, per package, for all packages (values in \%) }\end{aligned}$
\begin{tabular}{lrrrrr}
\hline Package & A & B & C & Total \\
\hline No. of evaluations & 18 & 19 & 19 & 56 \\
Motivating elements & & & & \\
$\quad$ Design & 5.6 & 21.1 & 26.3 & 17.9 \\
$\quad$ Curiosity & 27.2 & 57.9 & 68.4 & 50.0 \\
$\quad$ Fantasy & 0.0 & 0.0 & 26.3 & 8.9 \\
Goal-directed & 50.0 & 26.3 & 26.3 & 33.9 \\
$\quad$ Encouraging & 5.6 & 0.0 & 26.3 & 10.7 \\
Challenging & 27.8 & 26.3 & 21.1 & 25.0 \\
$\quad$ Activating students & 44.4 & 31.6 & 52.6 & 42.9 \\
Not motivating elements & & & & \\
$\quad$ Design & 5.6 & 5.3 & 10.5 & 7.1 \\
$\quad$ Inadequate reaction to & & & & \\
$\quad$ students responses & 5.6 & 26.3 & 21.1 & 17.9 \\
$\quad$ Dull & 50.0 & 21.1 & 10.5 & 26.8 \\
Discouraging & 0.0 & 31.6 & 0.0 & 10.7 \\
Making students passive & 11.1 & 10.5 & 0.0 & 7.1 \\
\hline
\end{tabular}

score on the antipole "objectives are realized more efficiently in another way" is considerably higher.

Especially for the drill and practice program, package A, "better realization of educational objectives" is considered as a strong point in the evaluations. In half of the evaluations of package A this point is of decisive importance.

"Motivating for students" is a strong point in more than half of the evaluations. Yet in nearly one-fifth of the evaluations the packages are considered as not motivating students. Especially teachers with much knowledge of computer applications evaluate the packages differently at this point. The motivational aspect of the packages is-as teachers perceive it-of all strong and weak points of most decisive importance for actual classroom use. Although still important it is striking that for teachers with no knowledge of computer applications the motivational aspect for students is less important than a "better realization of educational objectives". Table 9 shows what teachers perceive as motivating and not motivating elements of the packages.

As Table 9 shows, three elements seem to be motivating for students, viz. curiosity (packages $\mathrm{B}$ and $\mathrm{C}$ ), goal-directedness (package $\mathrm{A}$ ) and activating students (packages $\mathrm{A}$ and $\mathrm{C}$ ). In quite a number of evaluations "dull" (package $\mathbf{A}$ ) is mentioned as an element not motivating students.

\section{DISCUSSION}

In this section specifications for the design of courseware will be generated. Although the evidence in this study relates to only a small number of teachers' evaluations, generation of specifications can be justified. Formative and summative evaluation of courseware, whose design is based, among other things, on the proposed specifications, will take place in a further stage of the project, of which this study is a part.

For most teachers all three packages satisfied the necessary conditions for the use of courseware in the classroom. So it can be concluded that the courseware used in this study was--from the teacher's point of view-valid and friendly in its operation. From this evidence no design specifications can be derived.

For teachers deciding whether or not to use a certain courseware package in the classroom, the dimension of instrumentality (Table 5) seems of little importance. This is especially the case for teachers with knowledge of computer applications for the physics class. For teachers without knowledge of computer applications, instrumentality of a package seem to be a somewhat more relevant issue.

Concerning instrumentality Doyle and Ponder [4] notice that teachers often complain about the lack of clarity of an innovation. Fullan [3] states that next to lack of clarity, false clarity impedes educational change as well. Teachers at that stage of the decision making process probably perceive integration of courseware in the classroom in an oversimplified way. So, although only a few teachers in this study, particularly those with no knowledge of computer applications, consider 
instrumentality as an important dimension for the use of courseware, from literature on educational change $[2,3,6]$ it seems a relevant point.

Congruence refers to two issues (Table 6). First, is the content of a package relevant for the current curriculum, and second: does the package fit into daily classroom activities? The content of a package seems to be especially important for quite a number of teachers. The subject matter of all three packages, though different, is part of the junior high school physics curriculum. Different scores for the packages concerning content reflect the ideas and beliefs teachers have for physics education in junior high school. With caution it can be said that the results of this study show that guided discovery as an instructional approach (Table 7) is part of these ideas and beliefs. Courseware can be a concrete operationalization of teachers' ideas and beliefs. At least in the initial stage of the implementation process teachers perceive it in that way. Yet Goodlad [8] pointed out that there is a gap between teachers' expectations of what learning to provide and teaching practice. So courseware design should be directed towards carefully bridging the gap between expectations and practice.

A considerable change in the teacher's task influences classroom activities. It is striking that only half of the teachers in this study expect a change in their task. As the results indicate, quite a lot of physics teachers often work with groups of students. Guidance of group work surely will be one of the changes in the teacher's task as computers will be integrated into the curriculum. For physics teachers this probably is a relative simple aspect of the implementation process. However planning and management skills, due to limited availability of computers, will be an important aspect of the teacher's task as well. At this stage of the implementation process this seems to be underestimated by teachers.

Cost (Table 8) refers to the weighing of expected effort and benefits. Cost seems for all teachers in the study a very important dimension in the decision making process, particularly in relation to "motivating students" and "better realization of educational goals". At this moment in the implementation process "time saving" does not seem to be important. As the results of the study show, quite a lot of teachers with no or some knowledge of computer applications perceive the packages as motivating. However, within the group of teachers with much knowledge of computer applications opinions are different about the impact of the packages considered on the motivation of students. Motivating elements of the packages are "raising curiosity", "goal-directedness" and "activating students", which should be essential parts of courseware design.

Another important point in the decision making process for teachers is whether or not a package can be expected to improve the realization of educational objectives. For half of the teachers with no knowledge of computer applications a better realization of educational objectives was of most decisive importance. Teachers with much knowledge of computer applications were less optimistic about this point. In this study a better realization of goals was-as perceived by teachers--particularly evident with the package that practises skills in the reading of measuring-instruments. Walker [9] states that this type of courseware is consistent with the predominant emphasis on learning facts and skills in current education. The implications for the curriculum are, therefore, rather small. For initial computer use, especially for teachers with no computer knowledge, a drill and practice program seems to be adequate. Yet in the long run teachers have higher expectations of the use of courseware in the classroom.

It can be concluded that at the very first stage of the process leading to the integration of courseware in the curriculum it is important that a package is: (1) motivating for students; (2) providing a better realization of educational objectives; and (3) that its content is an operationalization of teacher's beliefs and ideas. The first two points imply that formative and summative evaluation in a classroom setting are an essential part of the courseware design process. As a result the courseware materials, probably in the form of a presentation of positive experiences with the courseware, can contain evidence about the impact of the courseware on students' motivation and about the realization of educational objectives compared with traditional teaching methods. The third point, bridging the gap between teacher's ideas and beliefs and teaching practice, indicates that the process of changing practice of teaching is crucial in the design process. Changing the practice of teaching requires more attention to be given to the stage of pre-active planning of teachers [10]. Accompanying teacher materials, as part of the courseware, should therefore activate teacher planning. If these aspects are realized in a courseware package it can be expected that a 
first positive step towards courseware use by teachers will have been taken. However, teachers at this stage of the implementation process seem to underestimate the complexity of the integration of courseware into the curriculum at several points. So already at this stage it is important to anticipate actual courseware use in the classroom to prevent teachers from a disappointing experience. Therefore, concrete teacher instructions as proposed by van den Akker et al.[10] should also be part of the design process.

\section{REFERENCES}

1. Bunderson C. V., Courseware. In Computer-Based Instruction: A State-of-the-Art Assessment (Edited by O'Neil Jr H. F.). Academic Press, New York (1981).

2. Fullan M. G., Miles M. B. and Anderson S. A., A conceptual plan for implementing the new information technology in Ontario schools. Ministry of Education, Ontario (1988).

3. Fullan M., The Meaning of Educational Change. Teachers College Press, New York (1982).

4. Doyle W. and Ponder G. A., The practicality ethic in teacher decision-making. Interchange 8, No. 3, 1-12 (1977-1978).

5. D'Arcy J. and Gardner J., Learning from teachers: teachers' perspectives of relevant courseware and training provision. Computers Educ. 12, 321-326 (1988).

6. Akker J. J. H. van den, The teacher as learner in curriculum implementation. J. Curric. Stud. 20, 47-55 (1988).

7. Centrum voor Onderwijs en Informatietechnologie (COI), Document onderwijskkundige en vakdidaktische beoordeling van courseware, versie 2, Enschede (1986).

8. Goodlad J. I., A Place Called School. McGraw-Hill, New York (1984).

9. Walker D. F.. Computers and the curriculum. In NSSE-Yearbook: Microcomputers and Education (Edited by Culbertson J. A. and Cunningham L. L.), pp. 22-39. NSSE, Chicago (1986).

10. Akker J. J. H. van den, Keursten P. and Plomp Tj., The integration of computer use in education. Int. J. educ. Res. In press. 